\title{
THE EFFECT OF ACROSTIC TECHNIQUES ON INCREASING THE MASTERY OF GERMAN PREPOSITIONS ON STUDENTS OF GERMAN LANGUAGE EDUCATION STUDY PROGRAM
}

\author{
Carolina Lestuny ${ }^{1}$, and Kunu Hanna Grietje ${ }^{1}$ \\ ${ }^{1}$ Germany Education Study Program, Pattimura University, Jl. Ir. M. Putuhena, Ambon \\ c.lestuny14@gmail.com
}

\begin{abstract}
This study aimed to examine the effect of acrostic techniques on increasing student mastery of Präpositionen, which was conducted from September to November 2020. This research was an experimental study with research subjects being college students of the German language study program in the third semester of the academic year 2020/2021. The instruments used in data collection in this study were Pre-test, and Post-test questions before and after the acrostatic technique were applied in the learning process with German prepositions. The results showed that the acrostic technique significantly affected the increasing mastery of Präpositionen college students (thit $=7.67>$ tab $=1.77$. Therefore, Acrostic techniques are recommended for use in präpositionen learning.
\end{abstract}

Keywords: Acrostic Technique, Präpositionen Mastery.

\section{Introduction}

Education plays an important role in creating quality human resources. Education can be defined by a continuous learning process that results can be obtained after the process of education.

In an effort to improve the quality of education, various breakthroughs are needed, both in curriculum development, learning innovation, and fulfilling educational facilities and infrastructure. Apart from these aspects, the use of methods and techniques in teaching also greatly supports the success of learning. In essence, learning methods or techniques will support the successful achievement of educational goals if they are adjusted to the conditions of learning. This is because the right learning techniques will accelerate the understanding of students which can affect the achievement of maximum learning outcomes. Meanwhile, various learning techniques will create a special attraction so that learning motivation will grow and will form active and creative students, thus fostering critical thinking skills and getting used to being active in learning. Learning is no longer to teachers-centered or lecturers-centered, but on students centered learning. Teachers or lecturers facilitate students so that they are free to learn.

One gap that we have felt and experienced so far is the lack of a correct and effective approach in carrying out the learning process. So far, we have only been fixated on the material and learning outcomes. We are only pursuing learning materials or subjects that must be completed at the end of the semester according to the RPP / RPS prepared. However, we often forget that it takes a separate process to be able to bridge the curriculum and learning outcomes. Therefore, to achieve success in learning, it must be supported by aspects including educators, textbooks used, learning media. And the methods or techniques applied. No matter how great the curriculum is designed, it is the educators who interact directly in the classroom. Educators have an important role because educators will transfer learning plans and make changes to students. For this reason, the role of educators greatly determines the success of the learners.

However, the reality is that there is still a very low learning motivation of students (college students), so that the learning outcomes do not achieve what is expected. Not to mention that educators (lecturers) often complain about the memory ability of students who

Received December $27^{\text {th }} 2020$, Revision February $04^{\text {th }} 2021$, Accepted for publication February $24^{\text {th }} 2021$.

Copyright (C) 2021 Published by FKIP - Unpatti, ISSN 2721-3110 
are lacking in remembering the material that has just been studied. They have difficulty in studying and understanding the German language grammar, especially in mastering the material of Präposition. Präposition material is considered difficult to learn, because there are several rules in its use, such as in proper use cases, whether it is a Dative or Accusative or Accusative-Dative or Genetiv combination. This is confirmed by Husin (1996: 43) that in the sentence structure the Präposition or preposition is located in front of a noun, interrogative pronoun or in front of a Personalpronomen. However, there are also some prepositions that are used after the noun. Furthermore, he suggested that there are several kinds of prepositions followed by Dative (Präposition mit dem Dative). Examples: von, nach, mit, seit, aus, zu, bei, entgegen, gegenüber, außer. Prepositions followed by Accusative (Präposition mit dem Accusativ). Example: um, für, gegen, durch, ohne, entlang. Furthermore, the preposition followed by Accusative and Dative (Wechsel präpositionen) are an, in, hinter, unter, auf, über, neben, vor, zwischen. Meanwhile, Gschossmann (1996: 33-38) argued that in German, nouns that follow a preposition are not always in the nominative form. Some prepositions are always followed by Accusative cases, some are followed by negative cases and others are followed by Genetiv cases. Mastery of Präposition material in German is considered very important, because the material is often used in the context of everyday conversation and writing.

In this study, researchers only conducted research in the three groups of Präposition, namely Präposition mit dem Dative, Präposition mit dem Accusativ, and prepositions / prepositions followed by Accusative and Dative (Wechselpräpositionen).

The cause of the difficulty of this material may be due to learning techniques used by lecturers when given so that students are difficult to understand and remember. Whereas in learning, explaining the subject is not appropriate or in accordance with foreign language learning material, in this case German, there are many learning techniques that can be used by an educator (lecturer). Not to mention the current covid period where learning carried out online requires creative learning by the lecturers.

Based on this concern, it is necessary to carry out applied tests or experiments using techniques that can help learners to achieve more satisfying results. One of the techniques that can be used is the acrostic technique. The acrostic technique is expected to stimulate students' creativity and ideas to more quickly grasp and remember the subject given. Acrostic technique is a technique or method used by teachers to make it easier for learners to remember a material or (preposition) by using or taking the initial, middle or end letters into a sentence or phrase. As stated by Hasanah (2010:1) that acrostic technique is a method used by teachers to make it easier for students to remember a material that they want to remember by using the initial, middle or final letters in a certain sentence or phrase. Furthermore, Markowitz in Pujino (2017) suggests that acrostic techniques use key letters to make abstract concepts more concrete so that they are easier to remember. As stated by Gunawan (2012: 124) that the Acrostic Technique, which is a memorization technique by taking the front letter, from the material to be memorized, then these front letters are combined and made an abbreviation or funny story. He then gave an example of using this technique to memorize the sequence of rainbow colors, namely
1. Red
2. Orange
3. Yellow
4. Green
5. Blue
6. Indigo
7. Purple

If you take the front letter of each color, you will find R, OYGBI, P (or MJKHBIU). These letters then made the abbreviation "Mejikuhibiniu" (in Indoneisan version which 
stand for Merah (red) Jingga(orange) Kuning (yellow) Hijau (green) Biru (blue) Indigo (indigo) and Ungu (purple).

Acrostic technique, in other words, is the keywords. Through the use of the Acrostic technique, the classroom atmosphere becomes lively and active and learners can quickly memorize and remember.

Based on the description above, it is deemed necessary to conduct research to answer the following problems: "How far do acrostic techniques have an effect on increasing the mastery of präpositionen by student of German language education?"

\section{Research Methods}

This research was a type of experimental research with one group pre-test and post-test design in testing the effect of the use of acrostic techniques on students' mastery of the German language study program FKIP-Ambon. The design used in this study can be seen in the following table:

Table 1. One Group Pre-test Post-test

\begin{tabular}{|c|c|c|}
\hline Pre-test & Treatment & Post-test \\
\hline $\mathrm{O}_{1}$ & $\mathrm{X}$ & $\mathrm{O}_{2}$ \\
\hline
\end{tabular}

(Sugiono, 2008: 111) [6]

Information:

O1 : Initial test (pre-test) before the treatment is given

$\mathrm{X}$ : Treatment

O2 : Post-test after the treatment is given.

This research was conducted in the 3rd semester of the German Language Study Program, with a sample of 14 students.

The instrument used in this study was a written test. The test given was in the form of pretest (before being given treatment) and post-test (after being given treatment) in the form of multiple choice (MC) with a total of 20 questions.

The data collection technique used in this study was a test used to measure the learning outcomes of the prepositions (präpositionen) college student. The test given was in the form of a pre-test before applying the acrostic technique, and a post-test after applying the acrostic technique, then the two test results are compared to find out whether there is a better change or not after using the acrostic technique.

The data analysis technique used in this study was the dependent T-test with the following formula:

Information:

$$
t=\frac{M d}{\sqrt{\frac{\sum x 2 d}{N(N-1)}}}
$$

$$
\begin{array}{lll}
\mathrm{t} & : & \text { Score } \\
\mathrm{Md} & : & \text { Mean } \\
\sum \mathrm{x} 2 \mathrm{~d} & : & \text { The sum of the deviation squares } \\
\mathrm{N} & : & \text { Degrees of freedom (measured in } \mathrm{N}-1
\end{array}
$$

(Arikunto, 2010: 349-350)

Received December $27^{\text {th }} 2020$, Revision February $04^{\text {th }} 2021$, Accepted for publication February $24^{\text {th }} 2021$.

Copyright (C) 2021 Published by FKIP - Unpatti, ISSN 2721-3110 


\section{Results and Discussion}

Data from Pre-test and Post-test results got treatment using acrostic technique shows in the table below:

Table 2. Student learning outcomes in Pre-Test and Post-Test

\begin{tabular}{|l|l|l|l|}
\hline No. & Subject & Pre-Test & Post-Test \\
\hline 1 & A & 55 & 65 \\
\hline 2 & B & 50 & 55 \\
\hline 3 & C & 65 & 70 \\
\hline 4 & D & 50 & 65 \\
\hline 5 & E & 75 & 85 \\
\hline 6 & F & 55 & 65 \\
\hline 7 & G. & 35 & 60 \\
\hline 8 & H & 75 & 85 \\
\hline 9 & I & 70 & 80 \\
\hline 10 & J & 55 & 75 \\
\hline 11 & K & 60 & 75 \\
\hline 12 & L & 20 & 35 \\
\hline 13 & M & 75 & 80 \\
\hline 14 & N & 75 & 85 \\
\hline
\end{tabular}

(Data source: Research Results, 2020)

The data in Table 1 above shows that Pre-test and Post results test after Prepositionen learning with the acrostic technique on 14 students, the lowest score obtained by students on the Pre-test is 20 (from a maximum value of 100) as many as one person and the highest score of 75 as many as 4 students. While on the Post-test, the lowest score obtained is 35 to as many as one person, and the highest score is 85 as many as 3 people.

Based on the test result data above, it can be seen that there are significant differences in values after applying acrostic techniques in learning.

Based on Statistical analysis showed that the value of $t_{\text {hit }}=7,67$ with $t_{\text {tab }}$ at a significance level of $95 \%(\alpha=0.05)$ and degrees of freedom $(\mathrm{df})=13$, was 1.77 . Thus $t_{\text {hit }}$ (7.67) $>t_{\text {tab }}$ (1.77) which shows that the acrostatic technique applied in learning German prepositions is very influential on the level of mastery by students. This means, the research hypothesis can be accepted so that it is proven that the application of acrostic techniques has a very positive effect towards increasing mastery of prepositions by college students.

One of the learning systems that is commonly applied is memorization, which is a habit used to recall the material that has been conveyed. Therefore, various techniques are needed to make it easier for learners to remember what they had learned, not only for today but continuously making it easier for them to learn. Therefore, as educators, it is necessary to study techniques or learning models so that learning can continue to be improved in an effort to make it easier for learners to master the foreign language that is being studied.

One of the techniques that can be used to improve a person's memory is the acrostic technique. The acrostic technique is a technique that can help foreign language learners which is proven to improve their ability to remember German prepositions. In fact, mastering prepositions is one of the challenges for language learners in mastering German prepositions. Acrostic technique is one of the methods used in learning. To make it easier for learners to remember a material that they want to remember by using the initial, middle or end letters in forming a certain sentence or phrase. Before being given treatment, students are given a pre-test, from the pre-test results, it was found that the German learning

Received December $27^{\text {th }} 2020$, Revision February $04^{\text {th }} 2021$, Accepted for publication February $24^{\text {th }} 2021$.

Copyright (C) 2021 Published by FKIP - Unpatti, ISSN 2721-3110 
outcomes of students were still low. Furthermore, from the description of the post-test result data above, it can be seen that student learning outcomes are quite significant after receiving treatment six times face-to-face online. By using the acrostic technique as an effort to increase knowledge of German prepositions according to each case in this case Accusative, Dative and Accusative-Dative. Therefore, the successful application of the Acrostic technique is supported by several advantages of the technique. Some of the advantages of the Acrostic technique in learning are that students quickly understand and remember and can sort out the right prepositions according to their respective cases.

Examples for the accusative case are: für, um, durch, ohne, gegen entlang and bis shortened to FUDOGEB; Prepositions that master Dative are ab, aus ausser, zu, bei, von, mit, seit nach, gegenüber abbreviated as 3A ZU BEVOMISE NAGE and prepositions that master Accusative and Dative namely an, auf, zwischen, unter, vor, über, hinter, in, neben is shortened to 2A ZU VÜHIN. Here students only need to memorize and remember.

\section{Conclusion}

From the results of research using acrostic techniques carried out online, it was found that the classroom atmosphere became more active and made it easier for students to quickly memorize and remember prepositions according to the case.

This acrostic technique is effectively used in learning. This can be seen from the data findings regarding the better mastery of students' preposition when using acrostic techniques than students before using acrostic techniques. Even though there are some students who have not obtained the expected / satisfactory grades.

Other than having a positive impact, the results of this research and hypothesis testing are also supported by using the $-t$ table test formula. That means that with the use of this acrostic technique, it is a good alternative that can be applied by educators in order to help learners during the learning process, and learning outcomes can be improved. Thus, this acrostic technique can improve students' mastery of prepositions.

\section{REFERENCES}

Arikunto, Suharsimi.2010.” Prosedur Penelitian” Jakarta: Universitas Terbuka.

Dewi Nur Hasanah.2010. Pengertian, Pelaksanaan, dan Manfaat Teknik Akrostik https://dewi-nur.blogspot.com/2010/12/pengertian-pelaksanaan-dan-manfaat.html

Gschossmann, Elke F. Henderschot.1996. Deutsche Grammatik.Jakarta: Penerbit Erlangga.

Gunawan.Adi W. 2012. Genius Learning Strategy. Petunjuk Praktis untuk Menerapakan Accelerated Learning. Jakarta: PT Gramedia Pustaka Utama.

Husin Ahmad.1996. Pengantar Bahasa Jerman.Dengan Metode Pendekatan Keterampilan Proses Untuk Menunjang Belajar Para Peminat Pemula Bahasa Jerman. Surabaya: Penerbit INDAH

Mhd.Pujiono. 2017. Penguasaan Kosakata Bahasa Jepang Melalui Teknik Akrostik Pada Mahasiswa Tingkat I Program Studi Sastra Jepang Universitas Sumatera Utara

Received December $27^{\text {th }} 2020$, Revision February $04^{\text {th }} 2021$, Accepted for publication February $24^{\text {th }} 2021$

Copyright (C) 2021 Published by FKIP - Unpatti, ISSN 2721-3110 
Edu Sciences J. Vol. 2, No. 1. March 2021, 49-54

Https://Www.Researchgate.Net/Publication/323547315 Penguasaan Kosakata B ahasa Jepang Melalui Teknik Akrostik Pada Mahasiswa Tingkat I Pro gram_Studi_Sastra_Jepang_Universitas_Sumatera Utara.Jogyakarta, 9 Desember 2017 PROCEEDING

Sugiono. 2008. Metode Penelitian Kualitatif Kuantitatif dan $R \& D ”$. Bandung: ALFABETA.

Received December $27^{\text {th }} 2020$, Revision February $04^{\text {th }} 2021$, Accepted for publication February $24^{\text {th }} 2021$

Copyright (C) 2021 Published by FKIP - Unpatti, ISSN 2721-3110 